DARIUSZ STĘPKOWSKI

Wydział Nauk Pedagogicznych

Uniwersytet Kardynała Stefana Wyszyńskiego

ORCID ID: http://orcid.org/oooo-ooo2-6855-1517

JOANNA PĘKALA

Wydział Pedagogiczny

Uniwersytet Warszawski

ORCID ID: http://orcid.org/oooo-0oo3-4554-1962
Forum Pedagogiczne $9(2019) 1$

Wpłynęło: 1.03.2019

Zatwierdzono do druku: 24.04.2019 DOI: 10.21697/fp.2019.1.22

\title{
Sprawozdanie z drugiego spotkania międzynarodowej grupy badaczy zajmujących się edukacją moralno-etyczną, Berlin 21-23 lutego 2019 roku
}

Międzynarodowa grupa skupia badaczy zajmujących się teoretycznymi podstawami wychowania moralnego i kształcenia moralno-etycznego oraz ich praktycznymi zastosowaniami w oświacie publicznej. Ukonstytuowała się podczas pierwszego spotkania, które miało miejsce na Wydziale Pedagogicznym Uniwersytetu Karola w Pradze (Republika Czeska) w dniach 22-23 czerwca 2018 roku. Uczestnicy tamtego wydarzenia i nowe osoby zainteresowane problematyką edukacji moralno-etycznej zgromadziły się ponownie w dniach 21-23 lutego 2019 roku w Instytucie Nauk o Wychowaniu Uniwersytetu Humboldtów w Berlinie. Byli to: Naděžda Pelcová i Andrea Hlaváčková-Fleischerová z Wydziału Pedagogicznego Uniwersytetu Karola w Pradze (Republika Czeska), Andrej Rajský z Wydziału Pedagogicznego Uniwersytetu Trnawskiego w Trnawie (Słowacja), Skaiste Laskiene z Uniwersytetu Nauk o Zdrowiu w Kownie (Litwa), Christo Todorov z Nowego Uniwersytetu Bułgarskiego w Sofii (Bułgaria), Nadiya Fedchyshyn z Państwowego Uniwersytetu Medycznego im. I. Ja. Horbaczewskiego w Tarnopolu (Ukraina), Zhengmei Peng i Tao Peng z Wschodnio-Chińskiego Uniwersytetu Państwowego w Szanghaju (Chiny), Shinichi Ushida z Uniwersytetu Soka w Tokio (Japonia) i autorzy niniejszego sprawozdania. Gospodarze trzydniowej debaty: Dietrich Benner, Roumiana Nikolova, Stanislav Ivanov i Mina Lumila byli związani z berlińskim instytutem. Ostatnia z osób-gospodarzy pochodzi z Finlandii i przygotowuje pod kierunkiem D. Bennera rozprawę doktorską właśnie na temat edukacji moralno-etycznej.

Członkowie grupy wyznaczyli sobie trzy cele do zrealizowania podczas spotkania w Berlinie - pierwszym było wydobycie specyfiki kształcenia moralno-etycznego z systemów szkolnych krajów, z których pochodzą; drugim - zaznajomienie 
się $\mathrm{z}$ instrumentem do mierzenia kompetencji moralno-etycznej, powstałym dzięki realizacji projektu badawczego ETiK i zastosowanym w badaniu ETiKInternational w Polsce i Austrii, a ostatnio również w Chinach. Trzecim celem było porównanie problemów moralnych, których dotyczą zadania testowe zawarte we wspomnianym instrumencie psychometrycznym, z tymi, które zawierają szkolne programy nauczania etyki w krajach reprezentowanych przez uczestników spotkania. Zaplanowano, że w wyniku trzydniowych dyskusji zostanie wypracowana struktura analityczna umożliwiająca porównanie kształcenia moralno-etycznego realizowanego w krajach pochodzenia członków grupy i wykaz zakresów tematycznych, które należy uwzględnić w narzędziu przygotowywanym do planowanego wspólnego badania terenowego.

W harmonogramie spotkania wyodrębniono trzy części. Pierwsza obejmowała popołudnie pierwszego i przedpołudnie drugiego dnia, kiedy to wysłuchano siedmiu wystąpień prezentujących powody wprowadzenia lekcji etyki do oświaty publicznej w krajach prelegentów, aktualny stan nauczania tego przedmiotu od strony dydaktycznej i wyzwania na przyszłość. Popołudnie drugiego dnia zarezerwowano na omówienie testu kompetencji etyczno-moralnych 15-latków i analizę badania przeprowadzonego z tym testem w Chinach. Przedpołudnie ostatniego dnia było poświęcone analizie porównawczej treści zadań testowych i programów nauczania oraz ustaleniu agendy zadań do wykonania przed kolejnym spotkaniem grupy w Trnawie. Poniżej w skrócie zrekapitulowano każdą z wymienionych części obrad.

Charakteryzując wprowadzenie w roku 1990 lekcji etyki do polskiej oświaty, D. Stępkowski i J. Pękala zwrócili uwagę na konflikt, który był z góry do przewidzenia między tym przedmiotem a katechezą szkolną. Etykę i religię uznano co prawda za alternatywne przedmioty obowiązkowe, ale praktyczna realizacja tego celu napotyka na szereg trudności organizacyjnych i ideologicznych. Do niedawna etyki nauczano tylko w niewielu szkołach w Polsce. Stan ten uległ poprawie w 2014 roku, kiedy to rząd Rzeczpospolitej Polskiej został na podstawie wyroku Trybunału Sprawiedliwości Unii Europejskiej zobligowany do zagwarantowania nauczania etyki wszystkim uczniom wyrażającym chęć uczestniczenia w takich lekcjach. Obecnie odsetek uczniów uczestniczących w zajęciach etyki wynosi nieco ponad 1. Tymczasem gwałtownie wzrasta liczba uczniów rezygnujących z uczenia się religii. W wyższych klasach szkoły podstawowej i szkołach ponadpodstawowych sięga ona 50 proc. Publiczną tajemnicą pozostaje fakt, że nie uczestniczą oni również w lekcjach etyki.

Prelegenci z Polski scharakteryzowali etykę jako przedmiot lekcyjny, omawiając stosujące się do niego zapisy Podstawy Programowej Kształcenia Ogólnego, programy nauczania i podręczniki szkolne. Zwrócili przy tym uwagę na ukierunkowanie kształcenia moralno-etycznego na zdobywanie przez uczących się kompetencji w zakresie wiedzy, umiejętności i sprawności społeczno-językowych.

Po dyskusji poświęconej wyjaśnieniu wątpliwości słuchaczy odnośnie lekcji etyki w oświacie polskiej głos zabrały Naděžda Pelcová i Andrea Hlaváčková-Fleischerová, 
które przedstawiły wykład na temat wychowania moralnego i kształcenia moralno-etycznego w Republice Czeskiej. Prelegentki podkreśliły, że w ich kraju między etyką a religią nie ma takiej rywalizacji jak w Polsce po prostu dlatego, że w szkołach publicznych nie naucza się religii. Dopiero w 2004 roku etyka została uwzględniona w krajowym programie nauczania jako nieobowiązkowy przedmiot szkolny. Od 2010 roku lekcje etyki prowadzone są na podstawie programu składającego się z 10 obszarów tematycznych, które referentki szczegółowo scharakteryzowały.

Od strony programowej można w Republice Czeskiej wyodrębnić trzy podejścia do nauczania etyki. Pierwsze zostało opatrzone wyrażeniem „forum prospołeczne”. Jest ono charakterystyczne głównie dla nauczycieli szkół podstawowych i akcentuje bardziej pragmatyczny niż teoretyczny sposób myślenia. Chodzi mianowicie o rozwijanie w młodym pokoleniu umiejętności zgodnego współżycia w społeczeństwie o zróżnicowanych poglądach politycznych i moralnych. Drugie podejście koncentruje w sobie zwolenników takiego prowadzenia lekcji etyki, które będzie rozwijać w uczniach kompetencje myślenia krytycznego. W tym ujęciu eksponuje się studiowanie tekstów z zakresu filozofii praktycznej (etyki) i literatury oraz dyskursywne rozważanie ukrytych w nich problemów egzystencjalnych. Trzecie podejście odzwierciedla nastawienie nauczycieli etyki ze szkół ponadpodstawowych, którzy postulują połączenie kwestii stricte filozoficznych z dydaktycznymi sposobami pracy w szkole.

Wystąpienie przedstawicielek Wydziału Pedagogicznego z Pragi wywołało ożywioną dyskusję. Po niej uczestnicy spotkania udali się na kolację.

Następnego dnia wznowiono obrady, począwszy od prezentacji przeglądu nauczania etyki na Litwie. Skaiste Laskiene z Uniwersytetu Nauk o Zdrowiu w Kownie przedstawiła bogato ilustrowaną prezentację multimedialną, w której wyeksponowała dwa kontrastujące ze sobą fenomeny: $\mathrm{z}$ jednej strony niemalże perfekcyjne przygotowanie lekcji etyki od strony dydaktycznej w dokumentach ministerstwa odpowiedzialnego za edukację litewską i ogromną popularność tego przedmiotu wśród uczniów na wszystkich poziomach kształcenia publicznego, $\mathrm{z}$ drugiej natomiast niepokojące dane Eurostatu, zgodnie z którymi Litwa przoduje na świecie pod względem liczby samobójstw, mimo że odsetek bezrobotnych jest najmniejszy z możliwych w Europie. Oczywiste jest, że nie można tych fenomenów odczytywać jak przyczyny i skutku, niemniej jednak kształtowanie poczucia sensu i szacunku wobec wartości życia należą do expressis verbis formułowanych celów nauczania etyki. Niestety, jak dotąd na Litwie nie prowadzono żadnych badań dotyczących efektów szkolnej edukacji etycznej.

Tradycyjnie po wystąpieniu nastąpiła dyskusja nad przedstawionym materiałem. Po niej o zabranie głosu poproszono Andreja Rajský'ego z Wydziału Pedagogicznego Uniwersytetu Trnawskiego. Swoją wypowiedź poparł on licznymi publikacjami, które powstały w związku z badaniami lekcji etyki, jakie od sześciu lat prowadzone są na reprezentowanym przez niego wydziale. Ogólnie można powiedzieć, że podobnie jak w Polsce etyka traktowana jest na Słowacji 
jako przedmiot konkurujący z religią. Niemniej jednak Słowacy są bardziej konsekwentni od Polaków w egzekwowaniu obowiązkowego charakteru obu tych przedmiotów, tzn. uczniowie rezygnujący z lekcji religii muszą uczęszczać na etykę. Różnica w proporcjach między obydwoma grupami wiąże się z wiekiem - im starsi uczniowie, tym mniejszy odsetek uczestniczących w lekcjach religii i tym większy tych, którzy biorą udział w szkolnej etyce. Dodatkową korzyścią etyki w szkole na Słowacji jest to, że ocena $\mathrm{z}$ tego przedmiotu liczy się przy przyjmowaniu kandydatów na niektóre kierunki studiów, takie jak politologia, socjologia, prawo itp., mimo że etyka nie jest przedmiotem maturalnym.

Również po tym wystąpieniu odbyła się dyskusja, a po niej zarządzono przerwę kawową. Dalszą część obrad rozpoczął Christo Todorov z Nowego Uniwersytetu Bułgarskiego w Sofii. Zrelacjonował on genezę nauczania etyki w szkolnictwie bułgarskim. Do edukacji publicznej przedmiot ten został wprowadzony dopiero po ostatniej reformie, którą zarządzono w 2015 roku. W odróżnieniu od Słowacji i Polski, gdzie lekcje etyki i religii stanowią względem siebie konkurencję, w Bułgarii $\mathrm{w}$ szkolnictwie publicznym nie naucza się w ogóle religii. Edukacja w tym zakresie należy do praw i obowiązków wspólnoty religijnej. Etyka została wprowadzona jako przedmiot obowiązkowy w ramach lekcji filozofii. C. Todorov z naciskiem podkreślił, że ma to wpływ zarówno na zakres tematyczny, jak i sposób nauczania. Będąc elementem obowiązkowej „alfabetyzacji filozoficznej” młodych Bułgarów, lekcje etyki są prowadzone w sposób scholastyczny i nie mają zbyt wiele wspólnego z rzeczywistością życiową czy społeczną. Nie dziwi więc, że uczniowie chętnie z nich rezygnują przy najbliższej nadarzającej się okazji. Jest nią ukończenie klasy X szkoły powszechnej. Przez dwa kolejne lata - do klasy XII - etyka jest nauczana jako przedmiot nadobowiązkowy.

Wdrażanie postanowień reformy zakończy się w 2022 roku. Zdaniem C. Todorova, badanie kompetencji uzyskiwanych na lekcjach etyki pomoże w zdobyciu orientacji, na ile rzeczywiście ten przedmiot spełnia pokładane w nim oczekiwania. Tak jak poprzednio zgromadzeni żywo dyskutowali nad zaprezentowanym - tym razem filozoficznie zorientowanym - formatem nauczania etyki.

Kolejne dwie prezentacje dotyczyły krajów Dalekiego Wschodu - Chin i Japonii. Obecność na spotkaniu dwóch pracowników naukowych ze Wschodnio-Chińskiego Uniwersytetu Państwowego w Szanghaju - Zhengmei Penga i Tao Peng - umożliwiła dotacja przyznana przez Fundację Aleksandra von Humboldta, która również pokryła część kosztów badania ETiK-Szanghaj, przeprowadzonego przez drugiego z wyżej wymienionych prelegentów w ramach jego pracy doktorskiej z pedagogiki. Praca ta została opublikowana w wydawnictwie LIT w 2018 roku i zatytułowana została Ethisch-moralische Kompetenzmessung in China: Eine vergleichende Studie im Rahmen des Projekts ETiK-International-Shanghai.

Chińscy prelegenci zwrócili uwagę na fakt, że etyka jako przedmiot nauczania szkolnego została wprowadzona w Państwie Środka dopiero w 2017 roku. Wyraża ją nazwa „Moralność i praworządność”, którą określa się lekcje z tego zakresu 
na wszystkich poziomach kształcenia publicznego. Ważną cechą wyróżniającą chiński model nauczania etyki jest bezwarunkowa kompatybilność tego przedmiotu z ideami politycznymi, które wyznaczają ogólne ramy dla całej edukacji. Do głównych zadań nauczania etyki zalicza się: wzmacnianie chińskiej kultury i tożsamości, wdrażanie socjalistycznego stylu wychowania i przyznanie marksizmowi uprzywilejowanego miejsca w systemie wartości wszystkich obywateli. Szczegółowy program nauczania etyki obejmuje trzy etapy kształcenia - klasy 1-6, 7-9 i 10-12. Upraszczając, można wyodrębnić trzy osie tematyczne, wokół których koncentrują się treści kształcenia: kultura, socjalistyczny ideał patriotyzmu i samostanowienie. W Szanghaju zostały zastosowane testy mierzące kompetencje moralno-etyczne uczniów, które dostosowano do wymienionych osi tematycznych. Ponadto w badaniu ETiK-International-Shanghai zastosowano metody jakościowe, które umożliwiły dotarcie do przeświadczeń moralnych i sposobów myślenia etycznego niemożliwych do psychometrycznego ujęcia. Przewiduje się przeprowadzenie dalszych badań dotyczących kompetencji moralno-etycznych, rozszerzając ich zakres na inne miasta i regiony Chin.

Wystąpienie gości z Chin wzbudziło duże zainteresowanie członków grupy nie tylko ze względu na egzotyczność kraju ich pochodzenia, lecz także na praktyczne zastosowanie narzędzi, których omówienie znalazło się w centrum drugiej części berlińskiego spotkania.

Po dyskusji jako ostatni zabrał głos Shinichi Ushida z Uniwersytetu Soka w Tokio. Omówił on nauczanie etyki w szkołach japońskich. Prelegent z Japonii rozpoczął od nakreślenia historycznego tła wychowania moralnego, które w Japonii łączy się nierozerwalnie z tamtejszym monarchicznym systemem władzy. Jego zdaniem w przeszłości cesarze Japonii wykorzystywali wychowanie moralne do indoktrynowania swoich poddanych. $Z$ tym przesłaniem prowadzono edukację moralną w japońskich szkołach już od 1890 roku, wyznaczając jej do zrealizowania trzy cele: 1) urabianie charakterów uczniów zgodnie z potrzebami ojczyzny, tzn. rodziny cesarskiej, 2) wyrabianie postawy lojalności wobec cesarza i ojczyzny i 3) kształtowanie gotowości oddania życia za ojczyznę. W tej formie prowadzono edukację moralną do końca drugiej wojny światowej. Po porażce wojennej Japonii usunięto kwestie moralne z programów nauczania. Zmieniło się to dopiero w 2014 roku, kiedy to temat wychowania moralnego i kształcenia moralno-etycznego powrócił ponownie do szkół, ale w zupełnie innym kontekście niż w przeszłości. Kontekst ten tworzy tym razem rosnąca świadomość potrzeby działania pedagogicznego nakierowanego na kwestie moralne i etyczne.

S. Ushida scharakteryzował opłakany stan przygotowania nauczycieli japońskich do prowadzenia lekcji etyki w szkołach. Chcąc przeciwdziałać temu, prelegent sam prowadzi kursy doszkalające i wykorzystuje podczas nich elementy berlińskiego narzędzia badawczego do oceny skuteczności kształcenia moralno-etycznego w Tokio.

Tak jak poprzednio zgromadzeni dyskutowali o naszkicowanym japońskim obrazie edukacji moralnej. Potem ogłoszono przerwę na obiad. 
Po przerwie przystąpiono do realizacji drugiego celu spotkania - zaznajomienia członków grupy z instrumentem służącym do mierzenia kompetencji moralno-etycznej, który powstał dzięki realizacji projektu badawczego ETiK w Berlinie i parokrotnie był wykorzystywany w badaniach przeprowadzonych w Warszawie, Wiedniu i Szanghaju. Prezentację przeprowadzili Roumiana Nikolova i Stanislav Ivanov. Zgromadzeni otrzymali do wglądu pełny zestaw zadań testowych, włącznie z tymi, które zostały przygotowane specjalnie na potrzeby projektu ETiKInternational-Shanghai. Został zaprezentowany zarówno proces tworzenia zadań testowych, jak również ich potwierdzona przez w/w badania empiryczne wartość diagnozowania kompetencji moralno-etycznej w zakresie trzech subkompetencji: 1) podstawowej wiedzy moralno-etycznej, 2) umiejętności sądzenia moralnego i 3) umiejętności planowania działania moralno-etycznego.

Po zakończeniu tej części spotkania członkowie grupy udali się na wspólną kolację. Obrady wznowiono następnego dnia.

Podczas trzeciej i ostatniej części berlińskiego zjazdu ustalono dwa zadania, jakie wykonają członkowie grupy do następnego spotkania: 1) opracowanie propozycji nowych zadań testowych odnoszących się do zakresów tematycznych nieuwzględnionych do tej pory w narzędziu badawczym i 2) sporządzenie według wspólnie przyjętego wzorca pisemnych analiz genezy i aktualnego stanu nauczania etyki w oświacie publicznej w każdym z krajów. Ustalono, że kolejne spotkanie odbędzie się w dniach 26-28 września 2019 roku w Trnawie. Przedyskutowano możliwość złożenia wspólnego wniosku badawczego w ramach nowego programu ramowego Unii Europejskiej „Horizon Europe”. Projekt wniosku zostanie opracowany przez członków grupy z Berlina, a wniosek złożony zostanie przez Wydział Pedagogiczny Uniwersytetu Karola w Pradze, który będzie pełnił funkcję lidera. Spotkanie w Berlinie zakończono wspólnym zdjęciem. 